\title{
Halomonas marisflavae sp. nov., a halophilic bacterium isolated from the Yellow Sea in Korea
}

\footnotetext{
1 Korea Research Institute of Bioscience and Biotechnology (KRIBB), PO Box 115, Yusong,

Taejon, Korea

2 Probionic Corporation. Bioventure Centre, Korea, Research Institute of Bioscience and Biotechnology (KRIBB), PO Box 115, Yusong, Taejon, Korea

3 Department of Food Science and Technology, Chungnam National University, Taejon, Korea

4 Department of Food and Life Science,

Sungkyunkwan University, Chunchun-dong 300, Jangan-gu, Suwon, Korea
}

\author{
Jung-Hoon Yoon, ${ }^{1}$ Seong Hyun Choi, ${ }^{3}$ Keun-Chul Lee, ${ }^{1}$ Yung Hee Kho, ${ }^{1}$ \\ Kook Hee Kang ${ }^{4}$ and Yong-Ha Park ${ }^{1,2}$
}

Author for correspondence: Yong-Ha Park. Tel: +82 42860 4620. Fax: +82 428604598. e-mail: yhpark@mail.kribb.re.kr

\begin{abstract}
A halophilic Gram-negative bacterial strain, $\mathrm{SW} 32^{\top}$, which was isolated from a sample from the Yellow Sea of Korea, was subjected to a polyphasic taxonomic study. This organism grew optimally in the presence of $0.5-12 \% \mathrm{NaCl}$. On the basis of phenotypic and phylogenetic data, strain $\mathrm{SW} 32^{\top}$ appeared to be a member of the genus Halomonas. Strain SW32 ${ }^{\top}$ formed a distinct evolutionary lineage within the phylogenetic clade comprising Halomonas species and the genera Zymobacter and Carnimonas. The 165 rDNA sequence of strain SW32 contains 19 signature characteristics of the genus Halomonas and the family Halomonadaceae. Strain $\mathrm{SW} 32^{\top}$ possessed a single polar flagellum, ubiquinone9 as the predominant respiratory lipoquinone and $C_{18: 1}, C_{16: 0}$ and $C_{16: 1} \omega 7 c$ and/or iso- $\mathrm{C}_{15: 0} \mathbf{2 0 H}$ as the major fatty acids. The DNA G+C content was $59 \mathrm{~mol} \%$. Levels of $16 \mathrm{~S}$ rDNA similarity between strain $\mathrm{SW}^{\mathrm{N}} \mathrm{2}^{\top}$ and the type strains of all validly described Halomonas species were $92 \cdot 0-93 \cdot 8 \%$. Strain SW32 ${ }^{\top}$ exhibited 165 rDNA similarity values of $92.7 \%$ to Zymobacter palmae IAM $14233^{\top}$ and $91.6 \%$ to Carnimonas nigrificans CECT $4437^{\top}$. These data indicate that strain $\mathrm{SW} 32^{\top}$ was related enough to members of the genus Halomonas to be placed as a new species within that genus. Therefore the name Halomonas marisflavae sp. nov. is proposed for strain $\mathrm{SW}^{2} 2^{\top}$. The type strain of the new species is strain SW32 ${ }^{\top}\left(={\mathrm{KCCM} 80003^{\top}}^{\top}=J C M 10873^{\top}\right)$.
\end{abstract}

Keywords: Halomonas marisflavae sp. nov., polyphasic taxonomy, marine bacterium

\section{INTRODUCTION}

The family Halomonadaceae was originally created by Franzmann et al. (1989) to accommodate the genera Halomonas (Vreeland et al., 1980) and Deleya (Baumann et al., 1983). However, Halomonas and Deleya, together with the genus Halovibrio (Fendrich, 1988), lacked differential phenotypic, particularly chemotaxonomic, characters (Franzmann \& Tindall, 1990; Skerratt et al., 1991). Phylogenetic analyses based on 16S rRNA gene sequences showed that the members belonging to the three genera form a monophyletic group (Dobson et al., 1993) and Volcaniella

\footnotetext{
Abbreviations: FAME, fatty acid methyl ester; MA, marine agar; TSA(B), trypticase soy agar (broth).

The GenBank accession number for the $16 \mathrm{~S}$ rDNA sequence of strain SW32 ${ }^{\top}$ is AF251143.
}

eurihalina is closely related to Halomonas elongata, the type species of the genus Halomonas (Mellado et al., 1995). Accordingly, the genera Halomonas, Deleya and Halovibrio and the species Paracoccus halodenitrificans were recently unified into a single genus Halomonas (Dobson \& Franzmann, 1996) and Volcaniella eurihalina was transferred to the genus Halomonas as Halomonas eurihalina (Mellado et al., 1995).

The genus Zymobacter, which was proposed by Okamoto et al. (1993), has been included in the family Halomonadaceae (Dobson \& Franzmann, 1996). The genus Chromohalobacter, with only a single species, Chromohalobacter marismortui (Ventosa et al., 1989), falls within the phylogenetic radiation occupied by Halomonas species, although Mellado et al. (1995) concluded that there are enough phenotypic differences to warrant classification of Chromo- 
halobacter as a genus separate from the Halomonas/Deleya complex. A new genus, Carnimonas, which contains only a single species, Carnimonas nigrificans, and forms a monophyletic group with Zymobacter palmae, has been described (Garriga et al., 1998). Despite its chemotaxonomic and physiological similarities, the authors did not include the genus Carnimonas within the family Halomonadaceae because it lacked 2 out of 15 descriptive signature characteristics in its 16S rRNA sequence (Garriga et al., 1998). Thus, the family Halomonadaceae currently possesses three genera; Halomonas (Vreeland et al., 1980; Dobson \& Franzmann, 1996), Chromohalobacter (Ventosa et al., 1989) and Zymobacter (Okamoto et al., 1993).

Members of the family Halomonadaceae are Gramnegative, either slight or moderate halophiles with straight or curved, rod-shaped cells. The family Halomonadaceae is characterized by having ubiquinone-9 as the predominant respiratory lipoquinone and $\mathrm{C}_{18: 1}$ plus cyclo $\mathrm{C}_{19: 0}$ and $\mathrm{C}_{16: 0}$ as the major fatty acids. This family is a member of the $\gamma$-subclass of the class Proteobacteria.

Recently, a halophilic Gram-negative bacterial organism, strain SW32, was isolated from a water sample of the Yellow Sea, Korea. The 16S rDNA sequence analysis indicated that this organism lies at the periphery of the phyletic radiation encompassed by the genus Halomonas and is phylogenetically related to the genera Zymobacter and Carnimonas. This observation suggested that other useful taxonomic data were also required for reliable classification of strain $\mathrm{SW} 32^{\mathrm{T}}$. Accordingly, the aim of the present study was to unravel the taxonomic status of strain $\mathrm{SW} 32^{\mathrm{T}}$ with a combination of phenotypic characters and detailed phylogenetic analysis.

\section{METHODS}

Bacterial strain and cultural conditions. Strain SW32 ${ }^{\mathrm{T}}$ was isolated from a water sample of the Yellow Sea in Boryung City, Korea, by the dilution plating technique on marine agar (MA) (Difco). For the investigation of morphological and physiological characteristics, strain SW32 ${ }^{\mathrm{T}}$ was cultivated on MA and broth (Difco) and trypticase soy agar (TSA) and broth (TSB) (BBL) at $28^{\circ} \mathrm{C}$. Cell biomass for respiratory lipoquinone analysis and DNA extraction was obtained from a marine broth culture. Strain SW $32^{\mathrm{T}}$ was cultivated at $28^{\circ} \mathrm{C}$ on a horizontal shaker at 150 r.p.m. and the broth culture was checked for purity microscopically before being harvested by centrifugation. For fatty acid methyl ester (FAME) analysis, cell mass of strain SW $32^{\mathrm{T}}$ was obtained from agar plates after growing for $3 \mathrm{~d}$ at $28^{\circ} \mathrm{C}$ on MA and TSA.

Morphological and physiological characterization. The morphology of cells was examined by phase-contrast microscopy and transmission electron microscopy (TEM). The presence or absence of flagella was examined using TEM with cells from an exponentially growing culture. The cells were negatively stained with $1 \%(\mathrm{w} / \mathrm{v})$ phosphotungstic acid and, after air-drying, grids were examined with a model CM-20 transmission electron microscope (Philips). Gram reaction was determined using the bioMérieux Gram Strain kit according to the manufacturer's instructions. Catalase activity was determined by bubble formation in a $3 \%$ hydrogen peroxide solution. Oxidase activity was determined by oxidation of $1 \%$ tetramethyl-p-phenylenediamine. Nitrate reduction and hydrolysis of aesculin were determined as described by Lanyi (1987). Hydrolysis of casein, gelatin, hypoxanthine, starch, Tween 80 , tyrosine and xanthine, and production of urease were determined as described by Cowan \& Steel (1965). Acid production from carbohydrates was determined by using the API $50 \mathrm{CH}$ system (bioMérieux). Other physiological tests were performed with the API 20NE system (bioMérieux). Growth under anaerobic conditions was determined after incubation in an anaerobic chamber with MA that was prepared anaerobically. Tolerance of $\mathrm{NaCl}$ was measured in TSB containing no $\mathrm{NaCl}$ or $0.5-30 \%(\mathrm{w} / \mathrm{v}) \mathrm{NaCl}$. Growth at various temperatures was measured on MA.

Chemotaxonomic characterization. The presence or absence of diaminopimelic acid in the peptidoglycan was determined as described by Komagata \& Suzuki (1987). Respiratory lipoquinones were extracted and purified as described by Komagata \& Suzuki (1987). The purified ubiquinones were dissolved in acetone and separated by reverse-phase HPLC. For quantitative analysis of cellular fatty acid compositions, a loop of cell mass was harvested and FAMEs were prepared and identified following the instructions of the Microbial Identification System (MIDI).

Determination of $\mathbf{G}+\mathbf{C}$ content. Chromosomal DNA was isolated and purified according to the method described previously (Yoon et al., 1996) with the exception that ribonuclease $\mathrm{T} 1$ was used together with ribonuclease $\mathrm{A}$. The $\mathrm{G}+\mathrm{C}$ content was determined by the method of Tamaoka \& Komagata (1984). DNA was hydrolysed and the resultant nucleotides were analysed by reverse-phase HPLC.

16S rDNA sequencing and phylogenetic analysis. 16S rDNA was amplified by PCR using the two universal primers as described previously (Yoon et al., 1998). The PCR product was purified with a QIAquick PCR purification kit (Qiagen) and the 16S rDNA was sequenced using the ABI PRISM BigDye Terminator Cycle Sequencing Ready Reaction kit (Applied Biosystems). The purified sequencing reaction mixtures were automatically electrophoresed using an Applied Biosystems model 310 automatic DNA sequencer. Alignment of sequences was carried out with CLUSTAL W software (Thompson et al., 1994). Gaps at the 5' and 3' ends of the alignment were omitted from further analyses. Phylogenetic trees were inferred by using three tree-making algorithms, neighbour-joining (Saitou \& Nei, 1987), maximum-likelihood (Felsenstein, 1981) and maximumparsimony (Kluge \& Farris, 1969) methods in the PHYLIP package (Felsenstein, 1993). Evolutionary distance matrices for the neighbour-joining method were calculated with the algorithm of Jukes \& Cantor (1969) with the DNADIST program. The stability of relationships was assessed by a bootstrap analysis of 1000 data sets by using the programs SEQBOOT and CONSENSE of the PHYLIP package.

\section{RESULTS}

\section{Morphology}

Strain SW $32^{\mathrm{T}}$ is a Gram-negative rod or oval. Cells are $0.9-1 \cdot 3 \mu \mathrm{m}$ wide and $1 \cdot 7-2 \cdot 3 \mu \mathrm{m}$ long after $3 \mathrm{~d}$ of growth on MA at $28{ }^{\circ} \mathrm{C}$. Cells are motile by means of 


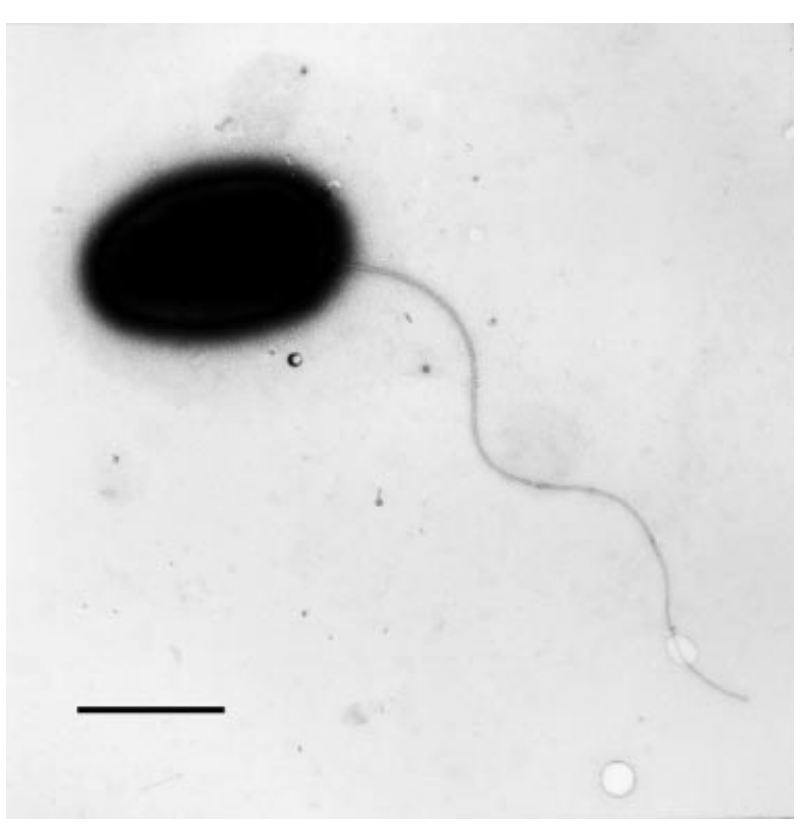

Fig. 1. Transmission electron micrograph of strain $S W 32^{\top}$ from an exponentially growing culture. Bar, $1 \mu \mathrm{m}$.

a single polar flagellum (Fig. 1). No spores were observed by phase-contrast microscopy. On TSA and MA, colonies appear yellow-orange, smooth, glistening and circular/slightly irregular. Colonies are convex on TSA and flat/slightly convex on MA.

\section{Cultural and physiological characteristics}

Strain SW $32^{\mathrm{T}}$ grew well in TSA and nutrient agar as well as MA. Strain SW $32^{\mathrm{T}}$ grew at $4-37^{\circ} \mathrm{C}$ with an optimum temperature of $25-30{ }^{\circ} \mathrm{C}$, but no growth occurred at temperatures above $39^{\circ} \mathrm{C}$. Optimum $\mathrm{pH}$ for the growth was $\mathrm{pH} 7 \cdot 0-8.0$ and growth was inhibited at $\mathrm{pH}$ values below 4.5. Strain $\mathrm{SW} 32^{\mathrm{T}}$ grew optimally in the presence of $0.5-12 \%(\mathrm{w} / \mathrm{v}) \mathrm{NaCl}$. It grew in the presence of $27 \% \mathrm{NaCl}$. Growth did not occur in the presence of $0 \% \mathrm{NaCl}$ and more than $28 \%$ $\mathrm{NaCl}$. Strain $\mathrm{SW} 32^{\mathrm{T}}$ grew under anaerobic conditions on MA. Strain SW $32^{\mathrm{T}}$ had catalase activity but no oxidase and urease activities. Aesculin and gelatin were hydrolysed, but no hydrolysis of casein, hypox- anthine, starch, Tween 80 , tyrosine and xanthine was observed. Nitrate was not reduced to nitrite. Arginine was not deaminated and indole was not produced. The following substrates were assimilated: glucose, arabinose, mannose, mannitol, gluconate, malate and citrate. Acids were produced from glycerol, erythritol, L-arabinose, ribose, D-xylose, galactose, D-glucose, Dfructose, D-mannose, arbutin, aesculin, salicin, cellobiose, maltose, lactose, melibiose, sucrose, trehalose, gentiobiose, D-turanose, D-lyxose and D-fucose and weakly produced from adonitol, mannitol and xylitol.

\section{Chemotaxonomic characteristics and DNA base composition}

Strain SW $32^{\mathrm{T}}$ did not contain any diaminopimelic acid as the diagnostic diamino acid in the cell wall peptidoglycan. The predominant respiratory lipoquinone found in strain $\mathrm{SW} 32^{\mathrm{T}}$ was ubiquinone with nine isoprene units (Q-9) (about 95\%). The fatty acid profile of strain SW $32^{\mathrm{T}}$ was similar on both TSA and MA and contained major amounts of saturated and unsaturated fatty acids (Table 1). The major fatty acids were $\mathrm{C}_{18: 1}, \mathrm{C}_{16: 0}$ and $\mathrm{C}_{16: 1} \omega 7 c$ and/or iso- $\mathrm{C}_{15: 0}$ $2 \mathrm{OH}$ (Table 1). The DNA $\mathrm{G}+\mathrm{C}$ content of strain SW $32^{\mathrm{T}}$, determined by HPLC, was $59 \mathrm{~mol} \%$.

\section{Phylogenetic analysis}

An almost complete 16S rDNA sequence of $1495 \mathrm{nt}$ (approx. 96\% of the Escherichia coli sequence) was determined for strain SW32 ${ }^{\mathrm{T}}$. This sequence contained four signature nucleotides defined for the genus Halomonas and 15 signature nucleotides associated with the family Halomonadaceae as described by Dobson \& Franzmann (1996) (Table 2). The phylogenetic analyses showed that strain SW $32^{\mathrm{T}}$ falls within the radiation of the cluster comprising the members of the family Halomonadaceae and the genus Carnimonas, and forms a distinct evolutionary lineage at the periphery of the phyletic radiation occupied by Halomonas species (Fig. 2). In the tree based on the neighbour-joining algorithm, strain $\mathrm{SW} 32^{\mathrm{T}}$ clustered to the clade comprising Halomonas species with a bootstrap resampling value of $68.2 \%$, and the relationship between this cluster and the cluster comprising the genera Zymobacter and Carnimonas was supported by bootstrap analysis at a confidence level

Table 1. Cellular fatty acid profiles of strain $S W 32^{\top}$ on TSA and MA

\begin{tabular}{|c|c|c|c|c|c|c|c|c|c|c|c|}
\hline \multirow[t]{2}{*}{ Medium } & \multicolumn{11}{|c|}{ Fatty acid composition (\%) } \\
\hline & $\mathrm{C}_{10: 0}$ & $\mathrm{C}_{12: 0}$ & $\mathrm{C}_{12: 0} 2 \mathrm{OH}$ & $\mathrm{C}_{12: 0} 3 \mathrm{OH}$ & $\mathrm{C}_{14: 0}$ & $C_{16: 0}$ & $\mathrm{C}_{17: 0}$ cyclo & $\mathrm{C}_{18: 0}$ & $\mathrm{C}_{18: 1} *$ & $\mathrm{C}_{19: 0}$ cyclo $\omega 8 \mathrm{c}$ & Summed feature $4 \dagger$ \\
\hline TSA & $1 \cdot 1$ & $2 \cdot 2$ & $1 \cdot 9$ & $9 \cdot 1$ & $0 \cdot 9$ & $28 \cdot 0$ & - & $1 \cdot 1$ & $42 \cdot 5$ & $0 \cdot 8$ & $12 \cdot 4$ \\
\hline MA & - & - & $1 \cdot 4$ & $6 \cdot 7$ & - & $31 \cdot 6$ & $2 \cdot 2$ & - & $42 \cdot 3$ & $4 \cdot 6$ & $11 \cdot 3$ \\
\hline
\end{tabular}

* Unresolved mixture of $\mathrm{C}_{18: 1} \omega 7 c, \mathrm{C}_{18: 1} \omega 9 t$ and $\mathrm{C}_{18: 1} \omega 12 t$.

$\dagger$ Summed feature represents $\mathrm{C}_{16: 1} \omega 7 c$ and/or iso- $\mathrm{C}_{15: 0} 2 \mathrm{OH}$, which could not be separated by GLC with the MIDI system. 
Table 2. 16S rDNA signature nucleotides characteristic of the family Halomonadaceae and the genus Halomonas

Data of the genera Halomonas and Zymobacter are from Dobson \& Franzmann (1996) and data for the genus Carnimonas are from Garriga et al. (1998). The large box shows the signature that defines the family Halomonadaceae and the small box shows the signature that defines the genus Halomonas. Positions are according to the Escherichia coli 16S rRNA numbering system.

\begin{tabular}{|c|ccccc|}
\hline & Position & Strain SW32 & Halomonas & Zymobacter & Carnimonas \\
\hline & & & & \\
$76-93$ & 6 bp stem & 6 bp stem & 6 bp stem & 6 bp stem \\
\cline { 2 - 5 } 484 & $\mathrm{~A}$ & $\mathrm{~A}$ & $\mathrm{~A}$ & $\mathrm{G}$ \\
486 & $\mathrm{C}$ & $\mathrm{C}$ & $\mathrm{C}$ & $\mathrm{U}$ \\
640 & $\mathrm{G}$ & $\mathrm{G}$ & $\mathrm{G}$ & $\mathrm{G}$ \\
660 & $\mathrm{~A}$ & $\mathrm{~A}$ & $\mathrm{~A}$ & $\mathrm{~A}$ \\
668 & $\mathrm{~A}$ & $\mathrm{~A}$ & $\mathrm{~A}$ & $\mathrm{~A}$ \\
669 & $\mathrm{~A}$ & $\mathrm{~A}$ & $\mathrm{~A}$ & $\mathrm{~A}$ \\
737 & $\mathrm{U}$ & $\mathrm{U}$ & $\mathrm{U}$ & $\mathrm{U}$ \\
738 & $\mathrm{U}$ & $\mathrm{U}$ & $\mathrm{U}$ & $\mathrm{U}$ \\
745 & $\mathrm{U}$ & $\mathrm{U}$ & $\mathrm{U}$ & $\mathrm{U}$ \\
776 & $\mathrm{U}$ & $\mathrm{U}$ & $\mathrm{U}$ & $\mathrm{U}$ \\
1124 & $\mathrm{U}$ & $\mathrm{U}$ & $\mathrm{U}$ & $\mathrm{U}$ \\
1297 & $\mathrm{U}$ & $\mathrm{U}$ & $\mathrm{U}$ & $\mathrm{U}$ \\
1298 & $\mathrm{C}$ & $\mathrm{C}$ & $\mathrm{C}$ & $\mathrm{C}$ \\
1423 & $\mathrm{~A}$ & $\mathrm{~A}$ & $\mathrm{~A}$ & $\mathrm{~A}$ \\
\hline & & $\mathrm{C}$ & $\mathrm{U}$ & $\mathrm{U}$ \\
1424 & $\mathrm{C}$ & $\mathrm{C}$ & $\mathrm{C}$ & $\mathrm{C}$ \\
1439 & $\mathrm{U}$ & $\mathrm{U}$ & $\mathrm{C}$ & $\mathrm{C}$ \\
1462 & $\mathrm{~A}$ & $\mathrm{~A}$ & $\mathrm{U}$ & $\mathrm{C}$ \\
1464 & $\mathrm{C}$ & $\mathrm{C}$ & $\mathrm{U}$ & \\
\hline
\end{tabular}

of $99 \cdot 4 \%$ (Fig. 2). The phylogenetic position of strain $\mathrm{SW} 32^{\mathrm{T}}$ was also confirmed in the trees generated with the maximum-likelihood and maximum-parsimony algorithms. The $16 \mathrm{~S}$ rDNA similarity values between strain $\mathrm{SW} 32^{\mathrm{T}}$ and the type strains of all validly described Halomonas species were in the range of 92.0-93.8\% . Strain SW32 ${ }^{\mathrm{T}}$ exhibited sequence similarity values of 92.3 and $92.7 \%$ to Chromohalobacter marismortui ATCC $17056^{\mathrm{T}}$ and Zymobacter palmae IAM $14233^{\mathrm{T}}$, respectively. The sequence similarity value between strain $\mathrm{SW} 32^{\mathrm{T}}$ and Carnimonas nigrificans CECT $4437^{\mathrm{T}}$ was $91 \cdot 6 \%$.

\section{DISCUSSION}

The phylogenetic inference based on $16 \mathrm{~S}$ rDNA sequences shows that strain $\mathrm{SW} 32^{\mathrm{T}}$ forms an intermediate evolutionary lineage between one cluster containing Halomonas species and the other cluster consisting of the genera Zymobacter and Carnimonas (Fig. 2). However, its $16 \mathrm{~S}$ rDNA sequence contains 4 signature nucleotides that define the genus Halomonas as well as 15 signature nucleotides characteristic of the family Halomonadaceae (Table 2). The results obtained in phenotypic and chemotaxonomic analyses make it possible to assign strain SW $32^{\mathrm{T}}$ to the genus Halomonas. The members of the family Halomonadaceae and the genus Carnimonas show no differences in their predominant respiratory lipoquinone, which is ubiquinone-9. While the major elements of their cellular fatty acid profiles are similar (Garriga et al., 1998; Franzmann \& Tindall, 1990; Okamoto et al., 1993), the three genera for which FAME analysis is available also have noteworthy differences in the composition of some fatty acids. The fatty acid profile of strain $\mathrm{SW} 32^{\mathrm{T}}$ is similar to those of members belonging to the genus Halomonas, but distinguished from those of the genera Carnimonas and Zymobacter (Dobson \& Franzmann, 1996; Franzmann \& Tindall, 1990; Garriga et al., 1998). The levels of $\mathrm{C}_{16: 0}$ are 28.0 or $31.6 \%$ in strain $\mathrm{SW} 32^{\mathrm{T}}$ (Table 1) and $16-32 \%$ in the members belonging to the genus Halomonas, whereas its mean level in Zymobacter palmae is $51 \%$ and its level in the type strain of Carnimonas nigrificans is $40 \%$ (Dobson \& Franzmann, 1996; Franzmann \& Tindall, 1990; Garriga et al., 1998; Okamoto et al., 1993). The level of $\mathrm{C}_{18: 1}$ in strain $\mathrm{SW} 32^{\mathrm{T}}$ is similar to the levels observed in Halomonas species, but much higher than the levels of Zymobacter palmae (mean level $11 \%$ ) and Carnimonas nigrificans CECT $4437^{\mathrm{T}}(13 \%)$ (Berendes et al., 1996; Garriga et al., 1998; Franzmann \& Tindall, 1990; Okamoto et al., 1993).

In addition, strain $\mathrm{SW} 32^{\mathrm{T}}$ is different from the genera Zymobacter and Carnimonas in some physiological properties, such as growth temperature, hydrolysis of 


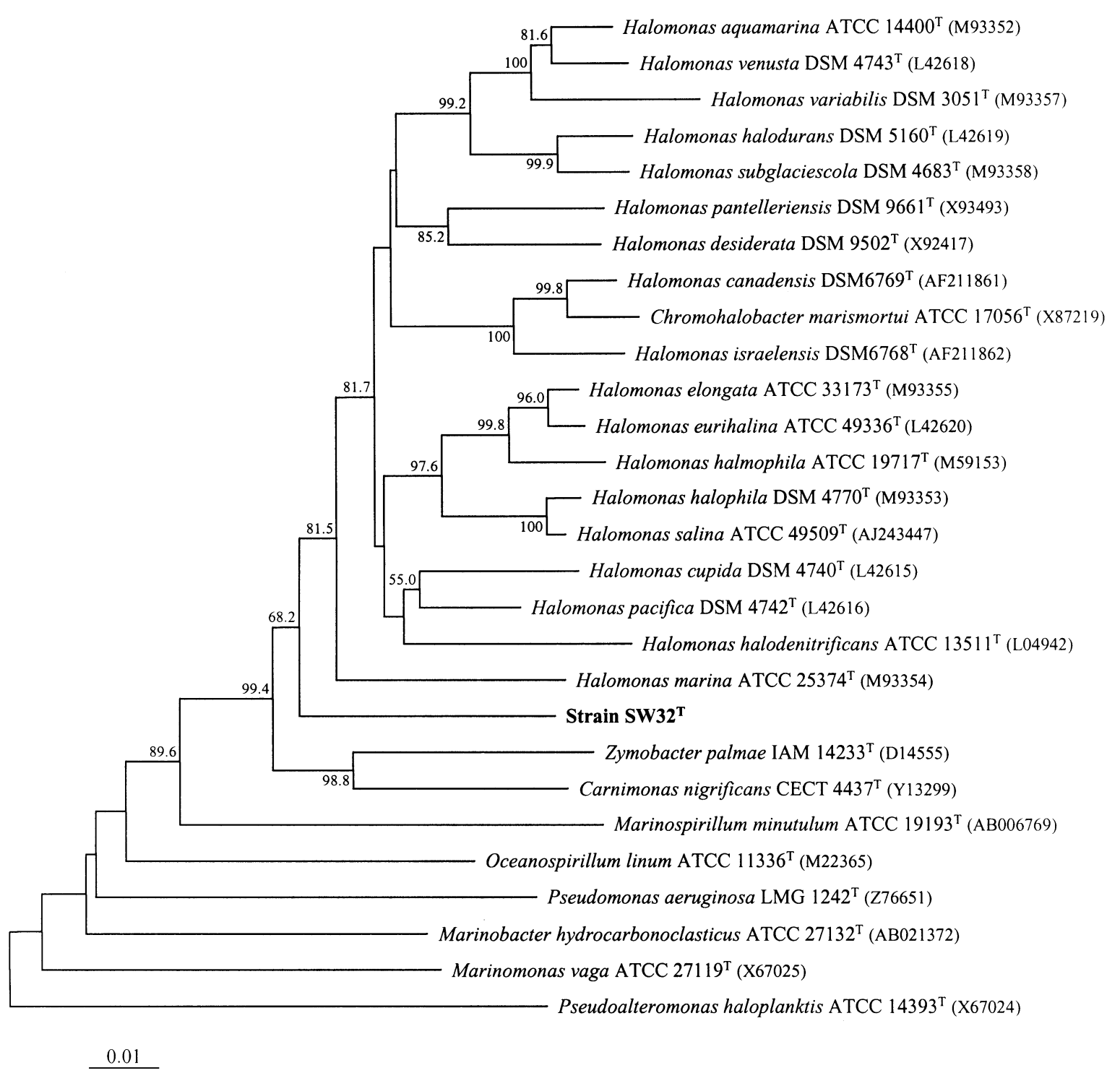

Fig. 2. Neighbour-joining tree showing the phylogenetic positions of strain $S W 32^{\top}$, members of the family Halomonadaceae and some related taxa based on 16S rDNA sequences. Scale bar represents 0.01 substitutions per nucleotide position. Bootstrap values (expressed as percentages of 1000 replications) greater than $50 \%$ are shown at the branch points.

starch and salt tolerance (Garriga et al., 1998; Okamoto et al., 1993). There is also a cellular morphological difference between strain $\mathrm{SW} 32^{\mathrm{T}}$ and the genera Zymobacter and Carnimonas. While cells of strain SW32 ${ }^{\mathrm{T}}$ have a single polar flagellum (Fig. 1), Carnimonas nigrificans has no flagellum (Garriga et al., 1998) and Zymobacter palmae has peritrichously flagellated cells (Okamoto et al., 1993). Therefore, both phenotypic and phylogenetic data indicate that it is appropriate to classify strain $\mathrm{SW} 32^{\mathrm{T}}$ as a member of the genus Halomonas. It is currently recognized that the genus Halomonas may be a heterogeneous complex that comprises several genera. It should be considered that the placement of strain SW $32^{\mathrm{T}}$ into the genus Halomonas may be changed if the genus Halomonas is taxonomically re-evaluated.
From the results of 16S rDNA similarity as well as the formation of a phylogenetic lineage distinct from the Halomonas species described previously, strain SW $32^{\mathrm{T}}$ can be clearly distinguished from other Halomonas species. The 16S rDNA similarity values of strain $\mathrm{SW} 32^{\mathrm{T}}$ to all other bacterial organisms as well as Halomonas species are less than $93 \cdot 8 \%$. Strain SW $32^{\mathrm{T}}$ showed phenotypic properties that are different from those of some other Halomonas species (Table 3). There are widely accepted criteria for delineating species in current bacteriology, stating that strains with a level of DNA relatedness less than $70 \%$ or with greater than $3 \%$ difference in $16 \mathrm{~S}$ rDNA similarity are considered as being different species (Wayne et al., 1987; Stackebrandt \& Goebel, 1994). Sequence similarity values obtained for strain $\mathrm{SW} 32^{\mathrm{T}}$ and the type 
Table 3. Phenotypic characteristics of strain $\mathrm{SW} 32^{\top}$ and some other Halomonas species

1, Strain SW32 $;$ 2, Halomonas elongata; 3, Halomonas eurihalina; 4, Halomonas halophila; 5, Halomonas salina (data for ATCC 49509 $)$; 6, Halomonas desiderata; 7, Halomonas cupida; 8, Halomonas pacifica; 9, Halomonas halodenitrificans; 10, Halomonas marina. Data from Romano et al. (1996), Mellado et al. (1995), Baumann et al. (1972, 1983), Vreeland et al. (1980), Quesada et al. (1984, 1990), Valderrama et al. (1991), Kocur (1984), Kersters \& De Ley (1984) and Palleroni (1984). Symbols: P, polar; Pr, peritrichous; + , positive reaction; - , negative reaction; $\mathrm{W}+$, weakly positive reaction; $\mathrm{v}$, variable reaction; ND, not determined.

\begin{tabular}{|c|c|c|c|c|c|c|c|c|c|c|}
\hline Characteristic & 1 & 2 & 3 & 4 & 5 & 6 & 7 & 8 & 9 & 10 \\
\hline Cell morphology & Rods or ovals & Rods & Short rods & Rods & Short rods & Rods & Rods & Rods & Cocci or short rods & Rods \\
\hline Flagellum & $\mathrm{P}$ & $\mathrm{P}$ or $\mathrm{Pr}$ & Absent & $\mathrm{P}$ or $\mathrm{Pr}$ & Absent & $\operatorname{Pr}$ & $\operatorname{Pr}$ & $\operatorname{Pr}$ & Absent & $\mathrm{P}$ \\
\hline Motility & + & + & - & + & - & + & + & + & - & + \\
\hline Oxidase & - & - & - & + & + & + & - & + & + & - \\
\hline Catalase & + & + & + & + & + & + & ND & ND & + & ND \\
\hline Nitrate reduction & - & + & + & + & + & + & + & - & + & - \\
\hline Growth in the presence of $0.5 \% \mathrm{NaCl}$ & + & + & $\mathrm{v}$ & - & - & + & + & + & - & + \\
\hline Growth in the presence of $30 \% \mathrm{NaCl}$ & - & + & - & + & - & - & - & - & - & - \\
\hline \multicolumn{11}{|l|}{ Hydrolysis of: } \\
\hline Aesculin & + & $\mathrm{v}$ & $\mathrm{v}$ & + & - & ND & + & + & - & - \\
\hline Casein & - & - & - & - & - & - & ND & ND & ND & ND \\
\hline Starch & - & - & ND & - & - & - & - & - & - & - \\
\hline Gelatin & + & $\mathrm{v}$ & + & - & - & - & ND & ND & - & - \\
\hline Urea & - & $\mathrm{v}$ & + & + & + & - & ND & ND & - & ND \\
\hline Tween 80 & - & ND & ND & - & - & - & ND & ND & - & - \\
\hline \multicolumn{11}{|l|}{ Acid production from: } \\
\hline Arabinose & + & - & - & - & - & ND & ND & ND & ND & ND \\
\hline Glucose & + & + & - & + & - & ND & ND & ND & - & ND \\
\hline Lactose & + & - & - & - & - & ND & ND & ND & ND & ND \\
\hline Mannitol & $\mathrm{w}+$ & - & - & - & - & ND & ND & ND & ND & ND \\
\hline $\mathrm{G}+\mathrm{C}$ content $(\mathrm{mol} \%)$ & 59 & $60-61$ & $59-66$ & 67 & 64 & 66 & $60-63$ & $67-68$ & 64-66 & $62-64$ \\
\hline
\end{tabular}

strains of all validly described Halomonas species are low enough to exclude the possibility of assigning strain SW $32^{\mathrm{T}}$ into one of these species. Accordingly, strain $\mathrm{SW} 32^{\mathrm{T}}$ should be given taxonomic status distinct from the Halomonas species described previously, although no DNA-DNA hybridization study was performed. On the basis of these data, we propose the creation of a new species, Halomonas marisflavae sp. nov., for strain $\mathrm{SW} 32^{\mathrm{T}}$. The properties of the new species are summarized below.

\section{Description of Halomonas marisflavae sp. nov.}

Halomonas marisflavae (ma.ris.fla'vae. L. gen. neut. n. maris of the sea; L. neut. adj. flavum yellow; L. gen. neut. n. marisflavae of the Yellow Sea, Korea).

Cells are rods or oval measuring $0.9-1.3 \mu \mathrm{m}$ wide and $1 \cdot 7-2 \cdot 3 \mu \mathrm{m}$ long after $3 \mathrm{~d}$ culture on $\mathrm{MA}$ at $28^{\circ} \mathrm{C}$. Gram staining reaction is negative. Non-sporeforming. Cells are motile by means of a single polar flagellum. Colonies are yellow-orange, smooth, glistening, circular/slightly irregular on both TSA and MA. Colonies are convex on TSA and flat/slightly convex on MA. Grows in the presence of $0.5-27 \%$ (w/v) $\mathrm{NaCl}$. Optimal $\mathrm{NaCl}$ concentration for growth is $0.5-12 \%(\mathrm{w} / \mathrm{v})$. Growth occurs at $4-37^{\circ} \mathrm{C}$ with an optimum of $25-30{ }^{\circ} \mathrm{C}$. Optimal $\mathrm{pH}$ for growth is $7 \cdot 0-8 \cdot 0$. Growth is inhibited at $\mathrm{pH}$ values below $4 \cdot 5$. Anaerobic growth occurs on MA. Catalase-positive. Oxidase- and urease-negative. Aesculin and gelatin are hydrolysed. Casein, hypoxanthine, starch, Tween 80 , tyrosine and xanthine are not hydrolysed. Nitrate is not reduced to nitrite. Indole is not produced. Arginine is not deaminated. Glucose, arabinose, mannose, mannitol, gluconate, malate and citrate are assimilated. Acids are produced from glycerol, erythritol, Larabinose, ribose, D-xylose, galactose, D-glucose, Dfructose, D-mannose, arbutin, aesculin, salicin, cellobiose, maltose, lactose, melibiose, sucrose, trehalose, gentiobiose, D-turanose, D-lyxose and D-fucose and weakly produced from adonitol, mannitol and xylitol. The predominant respiratory lipoquinone is ubiquinone-9. The major fatty acids are $\mathrm{C}_{18: 1}, \mathrm{C}_{16: 0}$ and $\mathrm{C}_{16: 1} \quad \omega 7 c$ and/or iso- $\mathrm{C}_{15: 0} 2 \mathrm{OH}$. The $\mathrm{G}+\mathrm{C}$ content is $59 \mathrm{~mol} \%$ (determined by HPLC). Isolated from a water sample of the Yellow Sea, Korea. The type strain is strain SW32 ${ }^{\mathrm{T}}$, which has been deposited at the Korean Culture Center of Microorganisms as KCCM $80003^{\mathrm{T}}$ and at the Japan Collection of Microorganisms as JCM $10873^{\mathrm{T}}$.

\section{ACKNOWLEDGEMENTS}

This work was supported by grant HS2701 from the Ministry of Science and Technology (MOST) of the Republic of Korea and by research fund of Probionic Corporation of Korea.

\section{REFERENCES}

Baumann, L., Baumann, P., Mandel, M. \& Allen, R. D. (1972). Taxonomy of aerobic marine eubacteria. J Bacteriol 110, 402-429.

Baumann, L., Bowditch, R. D. \& Baumann, P. (1983). Description of Deleya gen. nov. created to accommodate the marine species Alcaligenes aestus, A. pacificus, A. cupidus, A. venustus, and Pseudomonas marina. Int J Syst Bacteriol 33, 793-802.

Berendes, F., Gottschalk, G., Heine-Dobbernack, E., Moore, E. R. B. \& Tindall, B. J. (1996). Halomonas desiderata sp. nov., a new alkaliphilic, halotolerant and denitrifying bacterium iso- 
lated from a municipal sewage works. Syst Appl Microbiol 19, 158-167.

Cowan, S. T. \& Steel, K. J. (1965). Manual for the Identification of Medical Bacteria. London: Cambridge University Press.

Dobson, S. J. \& Franzmann, P. D. (1996). Unification of the genera Deleya (Baumann et al., 1983), Halomonas (Vreeland et al., 1980), and Halovibrio (Fendrich 1988) and the species Paracoccus halodenitrificans (Robinson and Gibbons, 1952) into a single genus, Halomonas, and placement of the genus Zymobacter in the family Halomonadaceae. Int J Syst Bacteriol 46, 550-558.

Dobson, S. J., McMeekin, T. A. \& Franzmann, P. D. (1993). Phylogenetic relationships between some members of the genera Deleya, Halomonas, and Halovibrio. Int J Syst Bacteriol 43, 665-673.

Felsenstein, J. (1981). Evolutionary trees from DNA sequences: a maximum likelihood approach. J Mol Evol 17, 368-376.

Felsenstein, J. (1993). PHYLIP (Phylogeny Inference Package) version 3.5. Seattle: Department of Genetics, University of Washington.

Fendrich, C. (1988). Halovibrio variabilis gen. nov., sp. nov., Pseudomonas halophila sp. nov. and a new halophilic coccoid eubacterium from Great Salt Lake, Utah, USA. Syst Appl Microbiol 11, 36-43.

Franzmann, P. D. \& Tindall, B. J. (1990). A chemotaxonomic study of members of the family Halomonadaceae. Syst Appl Microbiol 13, 142-147.

Franzmann, P. D., Wehmeyer, U. \& Stackebrandt, E. (1989). Halomonadaceae fam. nov., a new family of the class Proteobacteria to accommodate the genera Halomonas and Deleya. Syst Appl Microbiol 11, 16-19.

Garriga, M., Ehrmann, M. A., Arnau, J., Hugas, M. \& Vogel, R. F. (1998). Carnimonas nigrificans gen. nov., sp. nov., a bacterial causative agent for black spot formation on cured meat products. Int J Syst Bacteriol 48, 677-686.

Jukes, T. H. \& Cantor, C. R. (1969). Evolution of protein molecules. In Mammalian Protein Metabolism, pp. 21-132. Edited by H. N. Munro. New York: Academic Press.

Kersters, K. \& De Ley, J. (1984). Genus Alcaligenes Castellani and Chalmers 1919, 936 ${ }^{\mathrm{AL}}$. In Bergey's Manual of Systematic Bacteriology, vol. 1, pp. 361-373. Edited by N. R. Krieg \& J. G. Holt. Baltimore: Williams \& Wilkins.

Kluge, A. G. \& Farris, F. S. (1969). Quantitative phyletics and the evolution of anurans. Syst Zool 18, 1-32.

Kocur, M. (1984). Genus Paracoccus Davis 1969, 384 ${ }^{\mathrm{AL}}$. In Bergey's Manual of Systematic Bacteriology, vol. 1, pp. 399-402. Edited by N. R. Krieg \& J. G. Holt. Baltimore: Williams \& Wilkins.

Komagata, K. \& Suzuki, K. (1987). Lipids and cell-wall analysis in bacterial systematics. Methods Microbiol 19, 161-203.

Lanyi, B. (1987). Classical and rapid identification methods for medically important bacteria. Methods Microbiol 19, 1-67.

Mellado, E., Moore, E. R. B., Nieto, J. J. \& Ventosa, A. (1995). Phylogenetic inferences and taxonomic consequences of $16 \mathrm{~S}$ ribosomal DNA sequence comparison of Chromohalobacter marismortui, Volcaniella eurihalina, and Deleya salina and reclassification of $V$. eurihalina as Halomonas eurihalina comb. nov. Int $J$ Syst Bacteriol 45, 712-716.

Okamoto, T., Taguchi, H., Nakamura, K., Ikenaga, H., Kuraishi, H. \& Yamasato, K. (1993). Zymobacter palmae gen. nov., sp. nov., a new ethanol fermenting peritrichous bacterium isolated from palm sap. Arch Microbiol 160, 333-337.

Palleroni, N. J. (1984). Genus I. Pseudomonas Migula 1894, $237^{\mathrm{AL}}$. In Bergey's Manual of Systematic Bacteriology, vol. 1, pp. 141-199. Edited by N. R. Krieg \& J. G. Holt. Baltimore: Williams \& Wilkins.

Quesada, E., Ventosa, A., Ruiz-Berraquero, F. \& RamosCormenzana, A. (1984). Deleya halophila, a new species of moderately halophilic bacteria. Int J Syst Bacteriol 34, 287-292.

Quesada, E., Valderrama, M. J., Bejar, V., Ventosa, A., Gutierrez, M. C., Ruiz-Berraquero, F. \& Ramos-Cormenzana, A. (1990). Volcaniella eurihalina gen. nov., sp. nov., a moderately halophilic nonmotile Gram-negative rod. Int J Syst Bacteriol 40, 261-267.

Romano, I., Nicolaus, B., Lama, L., Manca, M. C. \& Gambacorta, A. (1996). Characterization of a haloalkalophilic strictly aerobic bacterium, isolated from Pantelleria Island. Syst Appl Microbiol 19, 326-333.

Saitou, N. \& Nei, M. (1987). The neighbor-joining method: a new method for reconstructing phylogenetic trees. Mol Biol Evol 4, 406-425.

Skerratt, J. H., Nichols, P. D., Mancuso, C. A., James, S. R., Dobson, S. J., McMeekin, T. A. \& Burton, H. (1991). The phospholipid ester-linked fatty acid composition of members of the family Halomonadaceae and genus Flavobacterium. A chemotaxonomic guide. Syst Appl Microbiol 14, 8-13.

Stackebrandt, E. \& Goebel, B. M. (1994). Taxonomic note: a place for DNA-DNA reassociation and 16S rRNA sequence analysis in the present species definition in bacteriology. Int $J$ Syst Bacteriol 44, 846-849.

Tamaoka, J. \& Komagata, K. (1984). Determination of DNA base composition by reverse-phase high-performance liquid chromatography. FEMS Microbiol Lett 25, 125-128.

Thompson, J. D., Higgins, D. G. \& Gibson, T. J. (1994). CLUSTAL $\mathrm{W}$ : improving the sensitivity of progressive multiple sequence alignment through sequence weighting, position specific gap penalties and weight matrix choice. Nucleic Acids Res 22, 4673-4680.

Valderrama, M. J., Quesada, E., Bejar, V., Ventosa, A., Gutierrez, M. C., Ruiz-Berraquero, F. \& Ramos-Cormenzana, A. (1991). Deleya salina sp. nov., a moderately halophilic Gram-negative bacterium. Int J Syst Bacteriol 41, 377-384.

Ventosa, A., Gutierrez, M. C., Garcia, M. T. \& Ruiz-Berraquero, F. (1989). Classification of 'Chromobacterium marismortui' in a new genus, Chromohalobacter gen. nov., as Chromohalobacter marismortui comb. nov., nom. rev. Int J Syst Bacteriol 39, 382-386.

Vreeland, R. H., Litchfield, C. D., Martin, E. L. \& Elliot, E. (1980). Halomonas elongata, a new genus and species of extremely salttolerant bacteria. Int J Syst Bacteriol 30, 485-495.

Wayne, L. G., Brenner, D. J., Colwell, R. R. \& 9 other authors. (1987). International Committee on Systematic Bacteriology. Report of the ad hoc committee on reconciliation of approaches to bacterial systematics. Int J Syst Bacteriol 37, 463-464.

Yoon, J.-H., Kim, H., Kim, S.-B., Kim, H.-J., Kim, W. Y., Lee, S. T., Goodfellow, M. \& Park, Y.-H. (1996). Identification of Saccharomonospora strains by the use of genomic DNA fragments and rRNA gene probes. Int J Syst Bacteriol 46, 502-505.

Yoon, J.-H., Lee, S. T. \& Park, Y.-H. (1998). Inter- and intraspecific phylogenetic analysis of the genus Nocardioides and related taxa based on 16S rDNA sequences. Int J Syst Bacteriol 48, 187-194. 